\title{
Regulating Computational Propaganda: Lessons from International Law
}

\author{
M.R. Leiser* \\ Leiden University
}

'None be so hardy to tell or publish any false news or tales, whereby discord, or occasion of discord or slander may grow between the King and his people, or the great men of the Realm'First Statute of Westminster, 1275

A historical analysis of the regulation of propaganda and obligations on states to prevent its dissemination reveals competing origins of the protection (and suppression) of free expression in international law. The conflict between the 'marketplace of ideas' approach favoured by Western democracies and the Soviet Union's proposed direct control of media outlets have indirectly contributed to both the fake news crisis and engineered polarisation via computational propaganda. From the troubled League of Nations to the Friendly Relations Declaration of 1970, several international agreements and resolutions limit state use of propaganda to interfere with 'malicious intent' in the affairs of another. Yet state and nonstate actors continually use a variety of methods to disseminate deceptive content sowing civil discord and damaging democracies in the process. In Europe, much of the discourse about the regulation of 'fake news' has revolved around the role of the European Union's General Data Protection Regulation and the role of platforms in preventing 'online manipulation'. There is also a common perception that human rights frameworks limit states' ability to constrain political speech; however, using the principle of subsidiarity as a mapping tool, a regulatory anomaly is revealed. There is a significant lack of regulatory oversight of actors responsible for, and the flow of, computational propaganda that is disseminated as deceptive political advertising. The article examines whether there is a right to disseminate propaganda within our free expression rights and focusses on the harms associated with the engineered polarisation that is often the objective of a computational propaganda campaign. The article concludes with a discussion of the implications of maintaining this status quo and some suggestions for plugging the regulatory holes identified.

Keywords: computational propaganda, freedom of expression, principle of subsidiarity, regulation of private propaganda

\section{INTRODUCTION}

The development of a coherent and comprehensive response to the 'fake news' crisis is at a crucial stage. With national and regional elections across Europe and United States (US) presidential and congressional elections in 2020, the continuous deployment of disinformation campaigns could further undermine democracy, sow further seeds of social unrest and manipulate voters to vote against their own rational interests. So far, the solutions proposed have been fragmented, compartmentalised and disparate. Recommendations for 'interagency 
cooperation', 'holistic approaches' across various sectors ${ }^{2}$ and additional platform regulation to tackle 'online harms' associated with digital disinformation have largely been ignored or are slow to be implemented. ${ }^{3}$ Rather, the European approach to preventing the dissemination of fake news has relied heavily on data protection law to constrain systems of advertising technology facilitating targeted advertising campaigns that threaten platform regulation to stem the tide of online disinformation. ${ }^{4}$ However, historically, propaganda has been defined as a form of communication sent with the objective of disrupting, manipulating, persuading, dissuading or misinforming recipients in a predetermined way. The communication is not necessarily based in factual evidence, but is intended to influence and manipulate. Although the European Union's (EU) General Data Protection Regulation (GDPR) empowers data subjects with powerful rights, in reality, these are rarely exercised. Users - the actors who suffer the harms associated with a propaganda campaign - have largely been left to the promotion of initiatives of the advertising industry ${ }^{5}$ and self-regulating platforms to reform their practices in such a way that any attempts at manipulation by nefarious actors is mitigated. ${ }^{6}$

Unlike in traditional war where competing sides battle over territory, in a propaganda campaign, the human brain is the subject of conquest. If one is not a combatant, then one is the subject of an invading force. Once a combatant wins over a sufficient number of minds, they have the power to influence society, policy and politics, and/or sow discord and civil unrest. While rational choice theorises that more information should be good for users, ${ }^{7}$ limited attention spans and information overload hinder proper discrimination between what is real and what is fake. Depending on the country, between 34\% (Germany) and 67\% (Greece) of EU

\footnotetext{
* Dr M.R. Leiser is Assistant Professor of Digital Technologies at Leiden Law School in The Netherlands. This paper is based on a Lecture delivered in the context of the 8th Annual Cambridge International Law Conference that took place on the 20th21st of March 2019 at the Faculty of Law of the University of Cambridge.

${ }^{1}$ European Data Protection Supervisor (EDPS), 'EDPS Opinion on Online Manipulation and Personal Data' (19 March 2018) Opinion 3/2018, 19 <https://edps.europa.eu/sites/edp/files/publication/18-03-19_online_manipulation_en.pdf > accessed 9 May 2019.

2 Annina Claesson, 'Coming Together to Fight Fake News: Lessons from the European Approach to Disinformation' (2019) 17 New Perspectives in Foreign Policy 13, 16 <https://csis-prod.s3.amazonaws.com/s3fspublic/NewPerspectives_APRIL2019_Claesson.pdf> accessed 5 June 2019; Commission, A Multi-dimensional Approach to Disinformation: Report of the Independent High Level Expert Group on Fake News and Online Disinformation (European Commission, Luxembourg, 2018) 20-21; Council of Europe Parliamentary Assembly, Resolution 1970 (2014), 'Internet and Politics: The Impact of New Information and Communication Technology on Democracy' (29 January 2014), para 19 <http://assembly.coe.int/nw/xml/XRef/Xref-XML2HTML-en.asp?fileid=20447\&lang=e> accessed 30 May 2019; Digital, Culture, Media and Sport Committee, Disinformation and 'Fake News': Final Report (HC 2017-19, 1791) 10-11.

${ }^{3}$ See for example, Department for Digital, Culture, Media \& Sport, Online Harms (White Paper, CP 57, 2019$) 6$.

${ }^{4}$ See for example, the actions of the French Data Protection Agency, CNIL; since the General Data Protection Regulation came into force in May 2018, CNIL has issued four public formal notices against actors involved in the advertising business: see 'Applications mobiles : mises en demeure pour absence de consentement au traitement de données de géolocalisation à des fins de ciblage publicitaire' ['Mobile Applications: Formal Notice for Lack of Consent to the Processing of Geolocation Data for Advertising Targeting Purposes'] (CNIL, 19 July 2018) <https://www.cnil.fr/fr/applications-mobiles-mises-endemeure-absence-de-consentement-geolocalisation-ciblage-publicitaire > accessed 18 July 2019. Google is also facing its first investigation by the European lead authority for 'suspected infringement' of the GDPR: 'Data Protection Commission Opens Statutory Inquiry into Google Ireland Limited' (Data Protection Commission, 22 May 2019) <https://www.dataprotection.ie/en/news-media/press-releases/data-protection-commission-opens-statutory-inquiry-googleireland-limited> accessed 5 June 2019

5 'Advertising Industry Response to the European Commission Public Consultation on Fake News and Online Disinformation' (23 February 2018) <https://eaca.eu/wp-content/uploads/2018/02/Fake-News_Advertising-Industry_PositionPaper_Final.pdf $>$ accessed 5 June 2019.

${ }^{6}$ Casey Newton, 'Facebook is Regulating its Products Before Lawmakers Force Them To' (The Verge, 12 April 2019) <https://www.theverge.com/interface/2019/4/12/18307091/facebook-integrity-updates-remove-reduce-inform-groups> accessed 5 June 2019.

${ }^{7}$ For a discussion of rational choice in the context of digital media, see Mark Leiser, 'The Problem with "Dots": Questioning the Role of Rationality in the Online Environment' (2016) 30 International Review of Law, Computers \& Technology 191.
} 
citizens follow news on social media, ${ }^{8}$ six out of ten shared news items are passed on by individual users without reading them first, ${ }^{9}$ a Channel Four study showed how only four per cent of individuals were able to identify fake news, and even digital-savvy students have difficulties discriminating fake news from real. ${ }^{10}$ Viral election news stories outperformed real news across Facebook ${ }^{11}$ as falsehoods spread farther, faster, deeper and more broadly than the truth. Although bots play a significant role in the spread of fake news, it is believable more than the truth because of the frailty of humans. False news 'spreads more than the truth because humans, not robots, are more likely to spread it'. ${ }^{12}$ Many of the ideas within propaganda are conspiracy theories that prompt a decline in the acceptance of science and pro-social behaviour. ${ }^{13}$ These have contributed to fractures in contemporary society.

With persistent ideological debates about the role of platforms in the recent upheaval of society, normative claims about platforms as individualised self-regulating marketplaces functioning to drive 'bad ideas' out are no longer accepted as fact. ${ }^{14}$ On the one hand, there is an argument that social media sites like Facebook and Twitter should be treated (therefore, protected) like they are part of the public sphere: they contribute to the marketplace of ideas and should be regulated (or not) in their role, as such. Conversely, the use of a variety of automated processes to disseminate content that benefit Facebook's bottom line ensure there is very little uniformity about the type of content users are exposed to. Contrary to much of the public discourse, users are rarely to blame for the dissemination of fake news. According to Guess et al, although users over 65 shared nearly seven times as many articles from fake news domains as the youngest age group, $90 \%$ of all respondents in the research study shared no stories from fake news domains and only $8.5 \%$ of users shared at least one article to their friends. ${ }^{15}$

For those keeping score, those advocating for more regulation of the automated processes used by social media platforms appear to have won the ideological battle. The European Commission has emphasised the need for a coherent strategy for the removal of illegal content ${ }^{16}$ and the Department for Digital, Culture, Media and Sport of the United Kingdom (UK) has gone further, publishing a proposal that calls for a 'duty of care' to prevent 'online harms'. ${ }^{17}$ Under the auspices of an independent regulator, platforms will likely deploy artificial intelligence and a variety of monitoring techniques to scan the volumes of user-generated content uploaded daily to scan for disinformation. ${ }^{18}$ Rather than regulate a) actors that deploy

\footnotetext{
${ }^{8}$ For detailed country reports, see Nic Newman and others, 'Reuters Institute Digital News Report 2019' (Reuters Institute for the Study of Journalism, 2019) 66-114 <https://reutersinstitute.politics.ox.ac.uk/sites/default/files/201906/DNR_2019_FINAL_1.pdf> accessed 18 July 2019.

9 Jayson DeMers, '59 Percent of You Will Share This Article Without Even Reading It' (Forbes, 8 August 2016) <https://www.forbes.com/sites/jaysondemers/2016/08/08/59-percent-of-you-will-share-this-article-without-even-readingit/\#347464bc2a64> accessed 6 February 2019.

${ }^{10}$ Jessica Goodfellow, 'Only 4\% of People Can Distinguish Fake News From Truth, Channel 4 Study Finds' (The Drum, 6 February 2017) <http://www.thedrum.com/news/2017/02/06/only-4-people-can-distinguish-fake-news-truth-channel-4study-finds> accessed 6 February 2019.

${ }^{11}$ Craig Silverman, 'This Analysis Shows How Viral Fake Election News Stories Outperformed Real News on Facebook' (BuzzFeed News, 16 November 2016) <https://www.buzzfeednews.com/article/craigsilverman/viral-fake-election-newsoutperformed-real-news-on-facebook $>$ accessed 18 July 2019.

12 Soroush Vosoughi, Deb Roy and Sinan Aral, 'The Spread of True and False News Online' (2018) 359 Science 1146, 1150.

${ }^{13}$ Sander van der Linden, 'The Conspiracy-Effect: Exposure to Conspiracy Theories (About Global Warming) Decreases ProSocial Behaviour and Science Acceptance' (2015) 87 Personality and Individual Differences 171, 173.

${ }^{14} \mathrm{See}$, for example, in relation to the inability of adolescents (a key demographic of social media and internet users) to distinguish between advertising and fake news: Sam Wineburg and others, 'Evaluating Information: The Cornerstone of Civic Online Reasoning' (Stanford History Education Group, 2016) <https://purl.stanford.edu/fv751yt5934> accessed 6 February 2019.

15 Andrew Guess, Jonathan Nagler and Joshua Tucker, 'Less Than You Think: Prevalence and Predictors of Fake News Dissemination on Facebook' (2019) 5 Science Advances 1, 3-4.

${ }^{16}$ Commission, 'Recommendation on Measures to Effectively Tackle Illegal Content Online' C(2018) 1177 final.

${ }^{17}$ Department for Digital, Culture, Media \& Sport (n 3) 64.

${ }^{18}$ Ibid 70.
} 
(advertisers), b) content (advertisements), or c) the processes used to target users (psychometric profiling and targeted advertising), the EU has opted for shifting the administrative burden and responsibility for users onto platforms. Failing to regulate computational propaganda is a failure of regulators in the fight for the protection of democracy.

Therefore, this article is structured as follows: first, it traces the foundation of the fundamental right to free expression to state obligations in international law not to disseminate propaganda. Because of the value given to the marketplace of ideas in Western democracies, the next section examines whether there is a right to disseminate propaganda in contemporary society. The next section argues that the lack of a coherent definition for 'fake news' has contributed to difficulties developing a coherent strategy for stemming the tide of its dissemination before moving to a critique of one of the methods used by actors that spread deceptive communications via Facebook's platform. A brief examination is posited of how the EU's system-based approach to mitigating the harms associated with online misinformation contributes to engineering of polarisation associated with computational propaganda. Finally, the article uses the principle of subsidiarity to identify the appropriate actors for the regulation of computational propaganda and identifies areas where regulatory reform is needed.

\section{REGULATING INTERNATIONAL PROPAGANDA}

In October 2018, Twitter released a dataset of content posted on its service identified as part of foreign influence operations, in particular coming from an infamous Russian company, the Internet Research Agency (IRA). ${ }^{19}$ The volume of released data was an astounding 275 GB. The move by the microblogging platform mirrored an earlier release by Facebook following the 2016 US election cycle after the discovery of disinformation operations taking place on its platform. ${ }^{20}$ Both platforms made data available to researchers to help understand what techniques were successfully used to drive activism and engagement. A transatlantic research lab concluded that more than 2 million images, GIFs, videos and broadcasts were targeted at communities to engineer polarisation to influence public discourse and elections. ${ }^{21}$ On this side of the Atlantic, Howard and Kollanyi determined that a statistically insignificant number of political bots, small pieces of software designed to undertake an automated task, generated a disproportionate amount of messages during the UK's referendum on continued membership of the EU. ${ }^{22}$ Sanovich convincingly argues that although Russia has historically sought to capitalise on existing divisions between the political left and right, the inability of her statecontrolled broadcast media ${ }^{23}$ to influence the Western world is partly responsible for the adoption of bots and trolls as key propaganda tools deployed by Russian actors like the IRA.

The obligation on states not to disseminate propaganda - hostile communications about one state sent across international borders - has been part of customary law since the French Revolution. Van Dyke could only identify one instance, a treaty in the late 1860s between

\footnotetext{
${ }^{19}$ Vijaya Gadde and Yoel Roth, 'Enabling Further Research of Information Operations on Twitter' (Twitter Blog, 17 October 2018) <https://blog.twitter.com/official/en_us/topics/company/2018/enabling-further-research-of-information-operations-ontwitter.html> accessed 6 June 2019.

20 Solomon Messing and others, 'Facebook URL Shares' (Harvard Dataverse, 11 July 2018) $<$ https://dataverse.harvard.edu/file.xhtml?persistentId=doi:10.7910/DVN/EIAACS/PMQG9X\&version=2.1 > accessed 6 June 2019.

${ }^{21}$ Ben Nimmo, Graham Brookie and Kanishk Karan, '\#TrollTracker: Twitter Troll Farm Archives' (Medium, 17 October 2018) <https://medium.com/dfrlab/trolltracker-twitter-troll-farm-archives-8d5dd61c486b> accessed 6 June 2019.

${ }^{22}$ Philip Howard and Bence Kollanyi, 'Bots, \#Strongerin, and \#Brexit: Computational Propaganda During the UK-EU Referendum' (COMPROP Research Note, 2016) 3-4 <https://arxiv.org/pdf/1606.06356.pdf> accessed 18 July 2019.

${ }^{23}$ In the early 2000s, all major broadcasters in Russia were nationalised and in 2014 the remaining three smaller and regional independent TV channels were subjected to Russian control or taken off the air: see Sergey Sanovich, 'Russia: The Origins of Digital Misinformation' in Samuel Wooley and Philip Howard (eds), Computational Propaganda: Political Parties, Politicians and Political Manipulation on Social Media (OUP, Oxford 2019) 21, 34 (note 7).
} 
Greece and Serbia to target Turkey with propaganda, that expressly contravened the custom not to broadcast propaganda into another state's territory. ${ }^{24}$ Finding consensus on the attribution of responsibility for private propaganda is far more challenging. As early as 1802, when Napoleon declared that it is a 'general maxim of [international law]' that states are bound to suppress private propaganda and punish those who purvey it, the UK rejected this interpretation of international law. ${ }^{25}$ Although Belgium passed laws making private activities against foreign governments a crime, when Bismarck complained about private propaganda, the Belgian government rejected that any state responsibility doctrine existed. ${ }^{26}$ Other states chose to adopt measures that imposed responsibility on the state for private propaganda. The Carlsbad Decrees of the Germanic Confederation of 1819, the Treaty of Amiens of 1801 and the Austro-Serbian Convention of 1881 all imposed state responsibility for private propaganda activities. Others tried to control it, but did not impose state responsibility, leaving customary law consistently violated and in a state of confusion.

Any attempt to regulate propaganda by private actors has been frustrated by not only advances in technology, but the development of mechanisms that facilitate its dissemination across territorial borders. Unsurprisingly, attempts to regulate private actor propaganda failed to take into account advances in technology. Many of the international agreements that facilitated communications from one state to another at the start of the $20^{\text {th }}$ century contained clauses permitting one state to refuse delivery of messages. However, these clauses were limited to messages deemed to be 'dangerous to the peace and security of the country'. ${ }^{27}$

Early attempts to regulate propaganda first drew on neutrality law ${ }^{28}$ before states started inserting anti-propaganda clauses into bilateral agreements of friendship and non-aggression in the 1920s and 1930s. ${ }^{29}$ In 1936, the League of Nations sponsored the first multilateral peacetime anti-propaganda effort. Signatories of the Convention Concerning the Use of Broadcasting in the Cause of Peace (the Treaty) were required to prohibit the use of broadcasting for propaganda or the spreading of false news by both state and private actors. ${ }^{30}$ Both, the UK, which favoured non-interference in matters of the press, and the Soviet Union, which supported government-enforced regulation and/or complete monopolisation of the press, signed the Treaty. Like the League of Nations, the Treaty was fraught with trouble and states immediately took steps to control information entering their territory. The Soviets reserved the right to jam radio broadcasts and Spain reserved the right to put a stop to all propaganda liable

\footnotetext{
${ }^{24}$ Vernon Van Dyke, 'The Responsibility of States for International Propaganda' (1940) 34 AJIL 58, 59.

${ }^{25}$ Ibid 65.

${ }^{26}$ Ibid 66.

${ }^{27}$ Elizabeth A Downey, 'A Historical Survey of the International Regulation of Propaganda' (1984) 5 Mich J Intl L 341,343 citing Convention Regarding Telephone and Telegraph Traffic between Denmark and Sweden (adopted 16 December 1921) 14 LNTS 196, art 4; Telegraphic Convention between French Equatorial Africa and the Belgian Congo (adopted 4 May 1922) 148 LNTS 61, arts 3 and 4; Convention for the Exchange of Radio Telegraphic Correspondence between Cuba and Mexico (adopted 29 June 1928) 124 LNTS 189, art 15; African Telecommunication Agreement (adopted 30 October 1935) 189 LNTS 51, arts 22 and 23; see also International Telecommunication Convention (adopted 21 December 1959) 12 UST 1761, TIAS No 4892, arts 31 and 32; International Telecommunication Convention (adopted 12 November 1965) 18 UST 575, TIAS No 6267, arts 32 and 33; International Telecommunication Convention (adopted 25 October 1973) 28 UST 2497, 2934, TIAS No 8572, arts 19 and 20. See also, generally, John B Whitton, 'The United Nations Conference on Freedom of Information and the Movement Against International Propaganda' (1949) 43 AJIL 73.

${ }^{28}$ Hague Convention (V) Respecting the Rights and Duties of Neutral Powers and Persons in Case of War on Land (adopted 18 October 1907, entered into force 26 January 1910) USTS 540, arts 4, 5 and 17(b) require states to limit and control propaganda.

${ }^{29}$ Supplementary Agreement to the German-Russian Agreement Concluded at Rapallo (adopted 5 November 1922) 26 LNTS 387, art 7; Convention for the Definition of Aggression between Romania, Poland, USSR, Afghanistan, Persia, Latvia, Estonia, and Turkey (adopted 3 July 1933) 147 LNTS 67, art 3, Annex; Convention for the Definition of Aggression between Rumania, USSR, Czechoslovakia, Turkey and Yugoslavia (adopted 4 July 1933) 148 LNTS 211, art 3, Annex; Convention for the Definition of Aggression between Lithuania and USSR (adopted 5 July 1933) 148 LNTS 79, art 3, Annex.

${ }^{30}$ International Convention Concerning the Use of Broadcasting in the Cause of Peace (adopted 23 September 1936, entry into force 2 April 1938) A/RES/841, arts 1,3,5.
} 
to 'affect internal order'. States established controls for licensing broadcasting facilities and began eliminating clandestine radio stations. ${ }^{31}$

In part because of a lack of any enforcement mechanism, and in part because the Treaty's noble attempt to promote 'mutual understanding between States' failed so miserably during World War II and 'propaganda liberally fuelled the hostilities', ${ }^{32}$ the United Nations General Assembly (UNGA) took up the question of how to regulate subversive and defamatory propaganda in its first ever assembly. ${ }^{33}$ Noting the dire consequences associated with propaganda used by the German and Italian governments in the run-up to and during the war, the UNGA acknowledged the need to regulate freedom of information to prevent its abuse with 'malicious intent'. ${ }^{34}$ Extensive debate ensued with countries like the UK and the US 'generally favouring the marketplace of ideas populated by the free flow of information to correct inaccuracies', whereas the Soviet Union and her allies supported government responsibility for, if not control of, the media. ${ }^{35}$ The Draft Convention on Freedom of Information also affirmed the 'right to listen' and 'declared no other grounds other than military security existed for peacetime censorship over the international transmission of news material' ${ }^{36}$

The text sent to the General Assembly forms the basis of article 19 of the International Covenant on Civil and Political Rights (ICCPR or Covenant), ${ }^{37}$ article 10 of the European Convention of Human Rights (ECHR) ${ }^{38}$ and article 11 of the EU's Charter of Fundamental Rights. ${ }^{39}$ The qualifications found in the text of the Draft Covenant all but ignore propaganda. The US, in particular, did not want any text in the United Nations (UN) Charter to empower states to limit free expression, but did manage to find agreement with the Soviets who wanted an article that authorised the regulation of any information qualifying as propaganda. In the end, both sides agreed to let article 26 of the Draft Covenant regulate state propaganda, but limited its application to propaganda for war or any advocacy of violence that constitutes incitement to discriminate, hostility or violence. ${ }^{40}$ For the US, any regulation of propaganda would conflict with freedom of expression and rights to impart and access information. Although US representatives approved article 19, the US did not ratify the ICCPR until 1992, in large part because of the limitations on communications found in article 19 and article 20 . Downey argues that this made the US position somewhat difficult to explain: 'first the United States seemed willing to accept a compromise on its freedom of information position, and then

\footnotetext{
${ }^{31}$ Charles G Fenwick, 'The Third Meeting of Ministers of Foreign Affairs at Rio de Janeiro' (1942) 36 AJIL 169, $174,189$.

32 Downey (n 27) 345.

${ }^{33}$ The UNGA adopted Resolution 59 (I) titled 'Calling of an International Conference on Freedom of Information': UNGA Res 59 (I) (14 December 1946) UN Doc A/RES/59. The Economic and Social Council sponsored the International Conference on Freedom of Information at Geneva in 1948 to study the measures for counteracting the persistent spreading of demonstrably false or tendentious reports which confuse the peoples of the world, aggravate relations between nations or otherwise interfere with the growth of international understanding, peace and security against a recurrence of Nazi, Fascist or Japanese aggression: ECOSOC, 'Freedom of Information: A Report on Contemporary Problems and Developments, With Recommendations For Practical Action, Submitted by Salvador P López to the Economic and Social Council' (6 May 1953) UN Doc E/2426, 7.

${ }^{34}$ UNGA Res 59 (I) (14 December 1946) UN Doc A/RES/59, preambular para 3.

${ }^{35}$ Downey (n 27) 345.

${ }^{36}$ Ibid 346, citing UNGA, 'Draft Convention on Freedom of Information: Note by the Secretary-General' (1963) UN Doc A/5443; see also UNGA 'Draft Convention on Freedom of Information: Note by the Secretary-General' (1967) UN Doc A/6658, Annex I.

${ }^{37}$ International Covenant on Civil and Political Rights (adopted 16 December 1966, entered into force 23 March 1976) 999 UNTS 171, art 19.

${ }^{38}$ Convention for the Protection of Human Rights and Fundamental Freedoms (European Convention on Human Rights, as amended), art 10.

${ }^{39}$ Charter of Fundamental Rights of the European Union (adopted 2 October 2000, entered into force 7 December 2000) 2012/C 326/02 (CFR), art 11.

40 Article 26 was drafted with the intention of being placed immediately after article 19, so when the ICCPR was adopted in 1966, it became article 20. The text of article 20 of the ICCPR is identical to article 26 of the Draft Covenant on Civil and Political Rights. See UNGA, 'Draft International Covenants on Human Rights: Note of the Secretary-General' (1966) UN Doc A/6342, Annex I, 19.
} 
it rejected that compromise'. ${ }^{41}$ As a consequence, propaganda aimed at peaceful regime change is not covered by the prohibition of subversive propaganda under current international law. ${ }^{42}$ Furthermore, the West wanted access to information from behind the Iron Curtain. In the battle of competing ideologies for the control of expression, the West won and freedom from interference by states was affirmed as a fundamental right. ${ }^{43}$ The use of propaganda as a weapon for disseminating disruptive speech is fundamental to understanding the rights-based frameworks for the protection of free speech we use today. Conflicting historical approaches to free speech in international law are rooted in attempts to regulate propaganda. ${ }^{44}$

\section{IS THERE A RIGHT TO PROPAGANDA?}

Freedom of expression is vital for the functioning of a modern and deliberative democracy; accordingly, any restrictions on speech is an affront to the Protagorean concept that the best way to protect free speech is to ensure a robust 'marketplace of ideas'. ${ }^{45}$ Advocates of the adversarial system practised at common law argue that a free trade in ideas advances the search for truth. This school of thought believes that '[w]hen false ideas are expressed by some citizens, the best response is not sanction by the state but vigorous rebuttal by other citizens'. ${ }^{46}$ Another school emphasises the need for free and unrestricted speech to exercise one's personal autonomy, ${ }^{47}$ arguing that free speech is a necessary precondition for not only discovering truth ${ }^{48}$ but self-expression. ${ }^{49}$ This school believes that individuals not only have the right to receive information uncensored by the state, 'they have the right to form their own beliefs and express them to others' and 'state suppression of speech therefore violates the "sanctity of individual choice" and is an affront to the dignity of the individual' ${ }^{50}$ Each of these theories of speech are reflected in the purposes of article 10 of the ECHR to ensure that the public has access to impartial and accurate information and a range of opinion and comment, reflecting, inter alia, the diversity of political outlook within the country and, furthermore, that journalists

\footnotetext{
${ }^{41}$ Downey (n 27) 358 (fn 67).

${ }^{42}$ Several early international legal instruments confirm the importance of the prohibition on influencing nationals of another state towards civil strife or insurrection. UNGA Res 290 (IV) (1 December 1949) UN Doc A/RES/290(IV) titled 'Essentials of Peace' asks states to 'refrain from any threats or act, direct or indirect, aimed at impairing the freedom, independence, or integrity of any other State, or at fomenting civil strife and subverting the will of the people in any State' (para 3). A similar obligation is contained in UNGA Res 2131(XX) (21 December 1965) UN Doc A/RES/2131(XX) titled 'Declaration on the Inadmissibility of Intervention in the Domestic Affairs of States and the Protection of Their Independence and Sovereignty', which proclaims that States are under an obligation not to 'organize, assist, foment, finance, incite or tolerate subversive, terrorist or armed activities directed towards the violent overthrow of the regime of another State, or interfere in civil strife in another State' (para 2). Similar provisions, although mainly directed at propaganda for war, are contained in the Declaration on Principles of International Law Concerning Friendly Relations and Cooperation among States in accordance with the Charter of the United Nation, UNGA Res 2625(XXV) (24 October 1970) UN Doc A/RES/2625(XXV).

${ }^{43}$ Universal Declaration of Human Rights (adopted 10 December 1948) UNGA Res 217 A(III) art 19; ICCPR, art 19; Conference on Security and Co-operation in Europe Final Act (adopted 1 August 1975) 14 ILM 1292 (Helsinki Final Act).

${ }^{44}$ Downey (n 27) 341.

${ }^{45}$ On self-government and democratic deliberation, see generally Alexander Meiklejohn, Free Speech and its Relation to SelfGovernment (Harper, New York 1948); Robert C Post, Constitutional Domains: Democracy, Community, Management (Harvard University Press, Cambridge 1995) 119-78; Cass Sunstein, Democracy and the Problem of Free Speech (Free Press, New York 1995); Harry Kalven, Jr, 'The New York Times Case: A Note on "The Central Meaning of the First Amendment"” (1964) Sup Ct Rev 191.

${ }^{46}$ Douglas Vick, 'Regulating Hatred' in Mathias Klang and Andrew Murray (eds), Human Rights in the Digital Age (The GlassHouse Press, London 2005) 41, 47.

${ }^{47}$ See RH Fallon Jr, 'Two Senses of Autonomy' (1994) 46 Stan L Rev 875; Harry H Wellington, 'On Freedom of Expression' (1979) 88 Yale L J 1105; C Edwin Baker, Human Liberty and Freedom of Speech (OUP, New York 1989) 194.

${ }^{48}$ William P Marshall, 'In Defense of the Search for Truth as a First Amendment Justification' (1995) 30 Ga L Rev 1.

${ }^{49}$ Martin H Redish, Freedom of Expression: A Critical Analysis (The Michie Company, Charlottesville 1984); David AJ Richards, 'Free Speech and Obscenity Law: Toward a Moral Theory of the First Amendment' (1974) 123 U Pa L Rev 45.

${ }^{50}$ Frederick F Schauer, Free Speech: A Philosophical Enquiry (CUP, Cambridge 1982) 19. See also Marshall (n 48).
} 
and other professionals working in audio-visual media should be free from state interference in imparting this information and comment. ${ }^{51}$

In Western democracies, any laws aiming to control the dissemination and content of speech could be frustrated by states' adherence to the very rights-based frameworks for the protection of free expression created in the 1950s. Before considering what can and should be done to control the dissemination of propaganda, it is necessary to establish the legality of the measure. Any national or regional speech regulation passed to regulate the dissemination of propaganda is constrained, in part, by international or domestic guarantees of freedom of expression. ${ }^{52}$ There are also a number of more specific provisions targeting particular types of speech. ${ }^{53} \mathrm{In}$ the UK, section 12 of the Human Rights Act 1998 (which gives effect to article 10 ECHR) specifically emphasises the importance of freedom of expression. Although article 10 imposes positive duties on states, section 4 of the Human Rights Act leaves scope for the UK Parliament to legislate in such a way that infringes article 10, providing it makes its intention to do so absolutely clear, even though this would then entail a breach of its international obligations.

If propaganda does not receive heightened protection by virtue of this provision then as long as the regulation does not come in the form of primary legislation, state controls will be subject to less intensive forms of judicial review, such as an assessment of the reasonableness of the measure in question. If, however, propaganda is considered protected expression, we have then to ask on what grounds, if any, it can be restricted through proportionate regulation and the value to be ascribed to its protection? On the one hand, our expression frameworks work to ensure journalists' freedom of expression on the internet, while, on the other, states' margin of appreciation legitimises the general obligation placed on the media to disseminate only accurate information. This obligation has always been restricted in application to broadcast media, but considering the structural decline of traditional, legacy media, this principle could be applied to platforms. The question is what methods of disseminating computational propaganda can be regulated and how.

\section{FROM 'FAKE NEWS' TO 'COMPUTATIONAL PROPAGANDA’}

With propaganda from public and private actors unlikely to abide any time soon, ${ }^{54}$ and no coherent legal framework to hold states responsible, the West has opted to adopt a variety of measures intended to protect the marketplace of ideas during democratic events from external interference. To thwart deceptive content designed to affect turnout or influence results, hackers from the US Cyber Command-described as a more autonomous and aggressive agency than its sibling the National Security Agency_took Russia's Internet Research Agency offline during the US congressional midterm elections. ${ }^{55}$ At the other end of the spectrum, the EU formed the East StratCom Task Force to analyse, debunk and publish 'fake news' stories. ${ }^{56}$

\footnotetext{
${ }^{51}$ Manole and others $v$ Moldova App no 13936/02 (ECtHR, 17 September 2009), para 100.

${ }^{52}$ ICCPR, art 19; ECHR, art 10; CFR, art 11.

${ }^{53}$ For instance, the prohibition in article 20 of the ICCPR on propaganda for war and the advocacy of certain forms of hatred that constitutes an incitement to discrimination, hostility or violence. These concerns also find reflection in specific treaties, such as the Council of Europe Framework Convention on Cybercrime (Budapest Cybercrime Convention) (opened for signature 23 November 2001, entered into force 1 July 2004) ETS 185.

${ }^{54}$ Samuel C Woolley and Philip N Howard, 'Computational Propaganda Worldwide: Executive Summary' (2017) Oxford Computational Propaganda Research Project Working Paper No 2017.11, 10-11 <http://comprop.oii.ox.ac.uk/wpcontent/uploads/sites/89/2017/06/Casestudies-ExecutiveSummary.pdf> accessed 10 June 2019.

55 Ellen Nakashima, 'US Cyber Command Operation Disrupted Internet Access of Russian Troll Factory on Day of 2018 Midterms' (The Washington Post, 27 February 2019) <https://www.washingtonpost.com/world/national-security/us-cybercommand-operation-disrupted-internet-access-of-russian-troll-factory-on-day-of-2018-midterms/2019/02/26/1827fc9e-36d611e9-af5b-b51b7ff322e9_story.html?noredirect=on\&utm_term=.2c0305ff5860> accessed 8 June 2019.

56 'Don't Be Deceived: EU Acts Against Fake News and Disinformation' (European Union External Action, 19 September 2017) <https://eeas.europa.eu/headquarters/headquarters-
} 
Beyond exposing 'fake news' stories, a self-regulatory EU-wide Code of Practice on Disinformation created for platforms and advertisers required signatories to delete fake accounts, label messages by bots, cooperate with fact-checkers and researchers to detect disinformation and to make fact-checked content more visible. ${ }^{57}$ Bernal, unconvinced by D'Ancona's definition ('the deliberate presentation of falsehood as fact') refers to 'fake news' as "falsehoods presenting themselves as both "real" and "news", in the sense that they are new, relevant, and important enough to be "newsworthy". 58 As the threshold of 'newsworthy' has not been reached, Bernal's narrow definition would not cover, for example, fake news claiming the earth was flat - no credible journalist would attach their name to this type of unsubstantiated claim; however, evidence-based accounts of people believing in this type of conspiracy theory would be considered newsworthy and 'real' under this definition. As Bernal's emphasis is on the harms associated with 'fake narratives', he downplays the role of custom advertising, dark posts, ${ }^{59}$ organised trolling and visual memes. ${ }^{60}$

Informed by research from cognitive and social psychology, 'fake news' may be defined as a deceptive form of media transmission and/or publishing that seeks to take advantage of our cognitive biases and errors in judgement to advance a commercial or political agenda. ${ }^{61}$ Drawing from a criminal law schema, it covers media transmissions that advance a commercial or political agenda (actus reus) and an intention to deceive (mens rea). ${ }^{62}$ This definition does not properly recognise the propagator's varied objectives or actors that innocently spread fake news, nor does it properly address the different methods used to disseminate deceptive content. Therefore, a refined definition can be posited: 'fake news' is a deceptive form of authentic-looking content, publishing or advertising that seeks to take advantage of our cognitive biases ${ }^{63}$ and errors in judgement to advance a commercial or political agenda. Its creator does not submit to content regulation. ${ }^{64}$ This broader definition not only integrates advertising and publishing into the definition, but also recognises three challenges in regulating fake news: first, the accidental inclusion of satirical sites that use 'humour, irony, exaggeration or ridicule to expose and criticise prevailing immorality or foolishness'; 65 second, the fact that creators of 'fake news', including state actors, rely on legacy protections for ensuring the fundamental right to political expression is given utmost consideration; ${ }^{66}$ and finally, it ensures that the distribution of advertising via automated systems

\footnotetext{
homepage_en/32408/Don\%27t\%20be\%20deceived:\%20EU\%20acts\%20against\%20fake\%20news\%20and\%20disinformatio $\mathrm{n}>$ accessed 8 June 2019.

${ }^{57}$ Commission, 'Code of Practice on Disinformation', 4-8

<https://ec.europa.eu/newsroom/dae/document.cfm?doc_id=54454> accessed 8 June 2019.

${ }^{58}$ Paul Bernal, 'Facebook: Why Facebook Makes the Fake News Problem Inevitable' (2018) 69 NILQ 513, 515.

59 Timothy Revell, 'Dark Ads Pick You Out' (2017) 235 New Scientist 8.

${ }^{60}$ Bernal (n 58) 515.

${ }^{61}$ This definition encapsulates the body of work posited by regulatory scholars like Cass Sunstein, behavioural economists like Richard Thaler and cognitive psychologists like Daniel Kahneman who question the folly in designing law from the premise of the rational actor and work on irrational dots in the online environment: see Mark Leiser, 'Regulating Fake News' (2017) BILETA Conference Paper <https://www.researchgate.net/publication/325618678_Regulating_Fake_News> accessed 9 June 2019. For further information see Christine Jolls, Cass Sunstein and Richard Thaler, 'A Behavioural Approach to Law and Economics (1998) 50 Stan L Rev 1471; Daniel Kahneman, Thinking, Fast and Slow (Penguin Books, London 2011); David MJ Lazer and others, ‘The Science of Fake News’ (2018) 359 Science 1094.

${ }^{62}$ Several scholars have argued that intention is an important factor: see Hunt Allcott, 'Social Media and Fake News in the 2016 Election' (2017) 31 Journal of Economic Perspectives 211, 213.

${ }^{63}$ Joachim I Krueger and David C Funder, 'Towards a Balanced Social Psychology: Causes, Consequences, and Cures for the Problem-Seeking Approach to Social Behaviour and Cognition' (2004) 27 Behavioural and Brain Sciences 313.

${ }^{64}$ On cognitive biases and errors in the online environment, see Leiser (n 7).

65 'Satire' (Oxford English Dictionary, 2013) <http://www.oed.com/viewdictionaryentry/Entry/171207> accessed 26 February 2019.

${ }^{66}$ Leslie Kendrick, 'Free Speech as a Special Right' (2017) 45 Philosophy and Public Affairs 87, 96.
} 
that facilitate the purchasing, delivery and optimisation of advertisements ${ }^{67}$ are captured alongside more personalised marketing campaigns that use 'custom audiences' mechanisms to target delivery. ${ }^{68}$

The European Data Protection Board has proposed further 'interagency cooperation' to address the spread of 'deliberate disinformation'. ${ }^{69}$ The European Data Protection Supervisor refers to online disinformation as 'managed content display' presented as most relevant for users but ordered to maximise revenue for the platform. ${ }^{70}$ The European Commission's independent High Level Expert Group on Fake News and Online Disinformation (HLEG) took a different approach, putting the term 'fake news' in a silo in favour of 'online disinformation' to legitimise discussions about the system of advertising techniques used to spread deceptive content. ${ }^{71}$ However, its definition, 'all forms of false, inaccurate, or misleading information designed, presented and promoted to intentionally cause public harm or for profit ${ }^{72}$ contains three high, but problematic, thresholds: first, 'public harm' and 'profit' confusingly mix motive with the effects on society. On their own, the targeted advertisements or dark posts discussed below would almost never qualify as satisfying the 'public harm' or 'profit' threshold. Secondly, the HLEG expressly states defamation is excluded from its definition. Yet some of the most infamous examples of fake news are textbook examples of libellous content. ${ }^{73}$ Although politicians are the least likely to exercise their right to protect their reputation under EU and national law, that does not mean that defamatory content is not deceptive.

It would be fair to say that disparate terminology has contributed to the bastardisation of the term, 'fake news'. Tambini convincingly argues that the term 'fake news' is so spoiled that the only responsible way to understand it is to first identify the beneficiaries of the term. Politicians and new populists, for example, deploy 'fake news' to undermine legitimate opposition and to resist fourth estate accountability. Historical losers use the term to claim that a result could only happen due to misinformation with some actors on the wrong end of an outcome arguing that electoral results are no longer legitimate due to 'fake news'. The term has also been used by mainstream media to discredit the 'wisdom of crowds' to drive a return of readers back to trusted news brands. ${ }^{74}$ With so many disparate approaches to regulating deceptive content and so much at stake, what can international law contribute, if anything, to the protection of the information ecosystem and democratic values of deliberation and pluralism?

Could the historical regulation of propaganda inform our understanding of 'fake news', 'disinformation', 'online manipulation' etc.? 'Propaganda' is a transmission across international borders that has the objective of disrupting, manipulating, persuading, dissuading

\footnotetext{
${ }^{67}$ Ashish Agarwal, Shun-Yang Lee and Andrew B Whinston, 'Word-of-Mouth in Social Media Advertising: "Likes" on Facebook Ads' (2017) <https://papers.ssrn.com/sol3/papers.cfm?abstract_id=3065564> accessed 18 July 2019.

68 Facebook Business, 'Custom Audiences' <https://www.facebook.com/business/learn/facebook-ads-reach-existingcustomers> accessed 10 June 2019

${ }^{69}$ EDPS (n 1) 5, 19

${ }^{70}$ Ibid 9.

${ }^{71}$ Commission (n 2) 6.

${ }^{72}$ Subramanian argues that propagation of deceptive content can be undertaken for profit: see Samanth Subramanian, 'Inside the Macedonian Fake-News Complex' (Wired, 12 July 2017) <https://www.wired.com/2017/02/veles-macedonia-fake-news/> accessed 10 June 2019.

${ }^{73}$ There is also a fine line between defamation and fake news. All instances of defamation are fake news, but not all fake news is defamatory. See Malik v Trump [2016] EWHC 2011 (QB) regarding the right of a Muslim man to sue for defamation in respect of statements made by then candidate Donald Trump in the course of the US election campaign 2016 about Muslims in London. See also Nadhim Zahawi MP v Press TV \& Press TV Limited [2017] EWHC 695 (QB) wherein a defamation claim was lodged against Iranian state media in respect of 'fake news' accusing a UK MP of involvement in selling oil to raise funds for ISIS.

${ }^{74}$ Damian Tambini, 'Fake News: Public Policy Responses' (2017) LSE Media Policy Project, Media Policy Brief 20, 9 〈http://eprints.lse.ac.uk/73015/1/LSE\%20MPP\%20Policy\%20Brief\%2020\%20-\%20Fake\%20news_final.pdf〉 accessed 9 June 2019.
} 
or misinforming recipients in a predetermined way. The communication is not necessarily based on factual evidence but has the intention to influence and manipulate. There are also clear similarities between a term like 'fake news' and the third world's use of the term 'false reports' to describe propaganda. However, propaganda is too analogue for the digitised world in which we live. Adding the word 'computational' does not just refer to the method of dissemination. It specifically acknowledges the role digital technologies have in adding levels of efficiency and scale to a propaganda campaign.

\section{ENGINEERING POLARISATION VIA COMPUTATIONAL PROPAGANDA}

The harms associated with computational propaganda are only beginning to be understood. Lewandowsky argues that misinformation contributes to suboptimal decisions by an illinformed society. ${ }^{75}$ The types of disinformation within a computational propaganda campaign have contributed to everything from public health crises $^{76}$ to a rise in climate change scepticism. ${ }^{77}$ More broadly, misinformation causes people to stop believing in facts $^{78}$ and reduces trust in official information, as well as government services and institutions. ${ }^{79}$ If users are only responsible for limited dissemination of deceptive content, and the EU's General Data Protection Regulation is meant to regulate the system of processing required for dissemination, then how does computational propaganda get into the information ecosystem?

When a propagandist wants to start a campaign, they can take advantage of the lack of regulatory oversight of political advertising in the UK and Facebook's automated content approval systems. The systematic abuse of both by Russian trolls resulted in thousands of promoted ads reaching an estimated 11.4 million people and 80,000 'organic' posts reaching 126 million users. ${ }^{80}$ The aim is to disrupt social cohesion and sow dissent in order to advance 'Putinism' - an ideology that advances Russian sovereignty while attacking the liberal and multilateral ideals of the West. ${ }^{81}$ Propaganda campaigns to influence the outcome of the 2016 US presidential election and the referendum of the UK's continued membership in the EU are not anomalies. Russian agents have been conducting computational propaganda operations on social media platforms for several years in many countries around the world. ${ }^{82}$

Youyou, Kosinski and Stillwell showed that a computer algorithm could infer people's personality on the basis of just ten Facebook likes more accurately than human work colleagues. ${ }^{83}$ This success rate increased with the number of likes and the program

\footnotetext{
${ }^{75}$ Stephan Lewandowsky, Ullrich KH Ecker and John Cook, 'Beyond Misinformation: Understanding and Coping with the "Post-Truth" Era' (2017) 6 Journal of Applied Research in Memory and Cognition 353, 354-355.

${ }^{76}$ HJ Larson, 'Addressing the Vaccine Confidence Gap' (2011) 378 The Lancet 526, 528-529.

77 PS Hart and Eric Nisbet, 'Boomerang Effects in Science Communication: How Motivated Reasoning and Identity Cues Amplify Opinion Polarization About Climate Mitigation Policies' (2012) 39 Communication Research 701, 711.

${ }^{78}$ Sander van der Linden and others, 'Inoculating the Public against Misinformation About Climate Change' (2017) 1 Global Challenges 1,5 .

${ }^{79}$ KL Einstein and DM Glick, 'Do I Think BLS Data are BS? The Consequences of Conspiracy Theories' (2015) 37 Political Behaviour 679, 693-695.

80 Leslie Shapiro, 'Anatomy of a Russian Facebook Ad' (The Washington Post, 1 November 2017) <https://www.washingtonpost.com/graphics/2017/business/russian-ads-facebook-anatomy/?utm_term=.9b133331bcd9> accessed 25 June 2019; see also Robert S Mueller, 'Report on the Investigation into Russian Interference in the 2016 Presidential Election: Volume I' (US Department of Justice, 2019) 14 <https://www.justsecurity.org/wpcontent/uploads/2019/04/Muelller-Report-Redacted-Vol-I-Released-04.18.2019-Word-Searchable.-Reduced-Size.pdf> accessed 26 July 2019.

${ }^{81}$ For an elaborate definition of the term 'Putinism' see Michael McFaul, 'Putinism and the 2016 US Presidential Election' (2019) Global Populisms and the International Diffusion Conference Paper, section I <https://fsi-live.s3.us-west-1.amazonaws.com/s3fs-public/putinisn2016election-3-10-19_1.pdf> accessed 10 June 2019.

${ }^{82}$ Sanovich (n 23) 21-40.

${ }^{83} \mathrm{Wu}$ Youyou, Michal Kosinski and David Stillwell, 'Computer-Based Personality Judgments are More Accurate than Those Made by Humans' (2015) 112 Proceedings of the National Academy of Sciences of the United States of America 1036, 1036.
} 
outperformed people's spouses — the best available human judges — when it had access to 300 likes. The more-than-one-billion Facebook users worldwide reveal much about their personality, whether they like it or not. ${ }^{84}$ The effects - and ethics — of such micro-targeting of advertising remain to be fully understood, but the current 'disruption in democratic governance' has been squarely linked to social media. ${ }^{85}$

Not only does psychometric testing, affinity/group profiling and automated/algorithmic dissemination contribute to the efficiency of behavioural and targeted advertising, dark posts sent to custom audiences via the advertising technology commonly found on social media platforms all contribute to the engineered polarisation that is often the objective of a computational propaganda campaign. A deceptive propagator has several methods at their disposal for the dissemination of content designed to influence and manipulate voters. Due to the complexity and variety, a campaign is usually undertaken using some form of automated process designed for disseminating content. For example, psychometric profiling ${ }^{86}$ and targeted advertising use personal data gathered from an array of data brokers and gatekeepers. ${ }^{87}$ That data is subsequently analysed and certain personality traits are attributed to specific users. ${ }^{88}$ These are used as the basis of a campaign, with political ads and fake news stories based on the user's psychological attributes and emotional responses to testing stimuli, targeted at users. User engagement can be measured, fed back into learning models and redeployed to gain further insights about how to algorithmically trigger users of a certain political disposition into making a non-rational political decision. Research has shown targeted ads mobilise especially young voters in competitive districts, yet with a small impact (less than $2 \%$ of voters are affected). ${ }^{89}$ In an ever-polarised world, not only does computational propaganda divide society, it mobilises society in a way that can impact elections. Groups also tend to harden their views over time, becoming even more resilient to alternative and moderating opinions.

Marketers and profilers directed dark posts, a form of social media advertisement, at custom audiences. Unlike other forms of Facebook marketing, dark (unpublished) posts are only visible to the target. However, Facebook's ad manager integrated 'shares' and 'likes' across multiple custom advertisements. This means that 100 custom advertisements could be delivered to 100 different target groups. Unique advertisements, visible in some cases to only one user, appeared to be far more popular than they were. Facebook's ads manager integrated the engagement across all 100 ads making political marketing messages appear far more popular than they were. ${ }^{90}$ By integrating user engagement from unique ads, Facebook

\footnotetext{
${ }^{84}$ John Synnott, Andria Coulias and Maria Ioannou, 'Online trolling: The case of Madeleine McCann' (2017) 71 Computers in Human Behaviour 70, 70 citing Arun Mal and Jenisha Parikh, 'Facebook and the right to privacy: Walking a tight rope' (2011) 4 National University of Juridical Sciences Law Review 299.

${ }^{85}$ Nathaniel Persily, 'Can Democracy Survive the Internet?' (2017) 28 Journal of Democracy 63, 75.

${ }^{86}$ Carole Cadwalladr, 'The Great British Brexit Robbery: How Our Democracy Was Hijacked' (The Guardian, 9 May 2017) <https://www.theguardian.com/technology/2017/may/07/the-great-british-brexit-robbery-hijacked-democracy> accessed 10 June 2019.

${ }^{87}$ Data collection is a form of data processing under EU law. See Regulation of the European Parliament and of the Council (EU) 2016/679 of 27 April 2016 on the protection of natural persons with regard to the processing of personal data and on the free movement of such data, and repealing Directive 95/46/EC (GDPR) [2016] OJ L119/1, art 4(2).

${ }^{88}$ For a good narrative of how Cambridge Analytica operated, see Carole Cadwalladr, 'British Courts May Unlock Secrets of How Trump Campaign Profiled US Voters' (The Guardian, 1 October 2017) <https://www.theguardian.com/technology/2017/oct/01/cambridge-analytica-big-data-facebook-trump-voters> accessed 17 July 2019. For further understanding of the techniques used by Cambridge Analytica, see Paul Bisceglio, 'The Dark Side of that Personality Quiz you Just Took' (The Atlantic, 13 July 2017) <https://www.theatlantic.com/technology/archive/2017/07/the-internet-is-one-big-personalitytest/531861> accessed 10 June 2019.

${ }^{89}$ Katherine Haenschen and Jay Jennings, 'Mobilizing Millennial Voters with Targeted Internet Advertisements: A Field Experiment. Political Communication' (2019) Political Communications (forthcoming).

${ }^{90}$ Matt Nelson, 'Facebook Dark Posts: Using the Dark Side of Facebook to Boost Conversions' (Klientboost, 2 January 2018) <https://klientboost.com/ppc/facebook-dark-posts/> accessed 10 June 2019.
} 
effectively permitted advertisers to use AstroTurfing techniques (a deceptive and illegal form of marketing that fools users into thinking that popularity is organic when, in reality, the support is artificial ${ }^{91}$ ) to manipulate its own users. There is evidence that social pressure can mobilise or depress voter turnout, ${ }^{92}$ and that social movements can mobilise quickly with little organisational structure. These can have turbulent outcomes and unpredictable results, including social upheaval. Lewandowsky et al argue that disinformation can also violate the public's right to be informed about risk. ${ }^{93}$ The micro-targeting of computational propaganda can also tip the balance of power between power brokers. Richer parties can buy more data, hire better data analysts and designers, and outbid poorer parties at the auction for possible voters.

The most infamous example comes from the Facebook-Cambridge Analytica scandal. ${ }^{94}$ Facebook's internal report into malicious use of its platform identified targeted data collection, content creation and false amplification as three major features of online information operations. ${ }^{95}$ By gathering information about which specific social causes users had previously shown an interest in, Facebook ads were targeted via direct dark posts at custom audiences. In some cases, individualised ads were only visible to single users as part of a campaign that measured their success. Several companies aggregate and maintain databases of sensitive behavioural data on billions of people and use that data to influence and reinforce existing biases and systematic errors we make when making decisions. These campaigns are designed based on data-drive predictive analytics, personalisation and, most importantly, A/B testing in order to influence behaviour on an unprecedented scale. For example, the Trump campaign ran $\mathrm{A} / \mathrm{B}$ testing to determine which ad variations outperformed others, with the campaign ultimately generating ' 100,000 distinct pieces of creative content' before they rolled 'out the strongest performers to broader audiences'. ${ }^{96}$

Often, automated campaigns are based on complex algorithms that can predict our political leanings, identify and target opposition voters for harassment or doxing, direct political advertising toward or to drown out opposition, validate fringe voters by making them appear more mainstream and 'acceptable', and direct unregulated political advertising en masse.${ }^{97}$ All of this data is then fed back into the advertising ecosystem using instant personalisation and predictive marketing with almost no oversight from the platform providers. Thus, propagators can pair decision data with algorithmic processing for provocative advertising campaigns; for example, Russian operatives buying ads in order to influence the US election ${ }^{98}$ or to stir up

${ }^{91}$ Commercial AstroTurfing is a prohibited practice under sections 2.1, 2.3 and 2.4 of the UK Code of Non-broadcast Advertising and Direct \& Promotional Marketing (CAP Code) of the Advertising Standards Agency (ASA). See 'CAP Code' (2010) <https://www.asa.org.uk/uploads/assets/uploaded/ce3923e7-94ff-473b-ad2f85f69ea24dd8.pdf> accessed 31 October 2017.

92 Robert M Bond and others, 'A 61-Million-Person Experiment in Social Influence and Political Mobilization' (2012) 489 Nature 295.

${ }^{93}$ Lewandowsky, Ecker and Cook (n 75).

${ }^{94}$ Commission, 'Tackling Online Disinformation: A European Approach' (Communication) COM (2018) 236 final.

95 Jen Weedon, William Nuland and Alex Stamos, 'Information Operations and Facebook' (Facebook, 27 April 2017) 6 <https://fbnewsroomus.files.wordpress.com/2017/04/facebook-and-information-operations-v1.pdf> accessed 25 June 2019.

${ }^{96}$ Joshua Green and Sasha Issenberg, 'Inside the Trump Bunker, With Days to Go' (Bloomberg, 27 October 2016) <https://www.bloomberg.com/news/articles/2016-10-27/inside-the-trump-bunker-with-12-days-to-go> accessed 25 June 2019.

${ }^{97}$ For a recent example, see David Ingram, 'Facebook Says 10 Million US Users saw Russia-linked Ads' (Reuters, 2 October 2017) <https://www.reuters.com/article/us-facebook-advertising/facebook-says-10-million-u-s-users-saw-russia-linked-adsidUSKCN1C71YM> accessed 6 October 2017.

${ }_{98}$ Elizabeth Dwoskin, Adam Entous and Craig Timberg, 'Google Uncovers Russian-Bought Ads on YouTube, Gmail and Other Platforms' (The Washington Post, 9 October 2017) <https://www.washingtonpost.com/news/theswitch/wp/2017/10/09/google-uncovers-russian-bought-ads-on-youtube-gmail-and-other-

platforms/?utm_term=.da193a347a56\&wpisrc=al_alert-COMBO-exclusive\%252Bnational\&wpmk=1> accessed 12 October 2017; Elizabeth Dwoskin, Adam Entous and Karoun Demirjian, 'Twitter Finds Hundreds of Accounts Tied to Russian Operatives' (The Washington Post, 28 September 2017) <https://www.washingtonpost.com/business/economy/twitter-finds- 
racial tensions after the deadliest mass shooting in US history. ${ }^{99}$ When an ad is unattributed to an identifiable advocate, but is also salient to the target recipient, the lack of transparency associated with computational propaganda generates polarisation of beliefs. Kahan et al have shown when such arguments are attributed to identifiable advocates, the impact of arguments on subjects is highly sensitive to the perceived cultural outlooks of the advocates. When persons of diverse cultural outlooks observe an advocate whose values they share advancing an argument they are predisposed to accept, and an advocate whose values they reject advancing an argument they are predisposed to resist, the usual association between persons' cultural world-views and their positions becomes more extreme. ${ }^{100}$

\section{SUBSIDIARITY PRINCIPLE AND THE REGULATION OF COMPUTATIONAL PROPAGANDA}

Any regulation of commercial and political speech rightly prompts queries about the infringement of expression rights. Despite speech protection at the forefront of democratic ideals, our society is not very protectionist when it comes to deceptive practices and demands substantial regulatory oversight of commercial advertising. We have strong frameworks for protecting consumers and take steps to ensure that citizens and outsiders alike do not skewer the integrity of political discourse. In April 2018, the EU Commission released a Communication on Disinformation arguing that the "primary obligation of state actors in relation to freedom of expression and media freedom is to refrain from interference and censorship and to ensure a favourable environment for inclusive and pluralistic debate'. ${ }^{101}$ However, the principle of subsidiarity provides the legal justification for taking proportional measures to restrict fundamental rights. The national authorities are generally in a better position than the supervisory bodies to strike the right balance between the sometimes conflicting interests of the Community and the protection of the fundamental rights of the individual. ${ }^{102}$ The principle of subsidiarity respects both the need for uniform and harmonious rules across the EU and member states' demands for greater recognition of autonomy. It is referred to as 'the most important of the principles underlying the convention' 103 and reflects a 'distribution of powers between the supervisory machinery and the national authorities which has necessarily to be weighted in favour of the latter'. ${ }^{104}$

At its heart, the principle recognises social organisation and presupposes the existence of certain social groups. Furthermore, it also developed as a response to excessive individualism in a way that permits a higher authority to intervene to the extent to which the lower authority (or the individual) has shown or proved incapable, and sets out the parameters for when it is appropriate for the higher authority to intervene. The former president of the European Court of Human Rights (ECtHR), Dean Spielmann, has suggested that the ECtHR in

hundreds-of-accounts-tied-to-russian-operatives/2017/09/28/6cf26f7e-a484-11e7-ade1-

76d061d56efa_story.html?tid=a_inl\&utm_term=.5b240591f5a5> accessed 12 October 2017.

99 Adam Entous, Craig Timberg and Elizabeth Dwoskin, 'Russian Facebook Ads Showed a Black Woman Firing a Rifle, Amid Efforts to Stoke Racial Strife' (The Washington Post, 2 October 2017) $<$ https://www.washingtonpost.com/business/technology/russian-facebook-ads-showed-a-black-woman-firing-a-rifle-amidefforts-to-stoke-racial-strife/2017/10/02/e4e78312-a785-11e7-b3aa-c0e2e1d41e38_story.html?utm_term=.5ef7e0911363> accessed 12 October 2017.

100 Dan M Kahan and others, 'Biased Assimilation, Polarization, and Cultural Credibility: An Experimental Study of Nanotechnology Risk Perceptions' (2008) Harvard Law School Program on Risk Regulation Research Paper 8-25 <https://papers.ssrn.com/sol3/papers.cfm?abstract_id=1090044> accessed 26 July 2019.

${ }^{101}$ Commission (n 94) 1.

102 For an example of the ECtHR making this argument, see Handyside v The United Kingdom App no 5493/72 (ECtHR, 7 December 1976) para 48.

${ }^{103}$ Rolv Ryssdal, 'The Coming of Age of the European Convention of Human Rights' (1996) 1 EHRLR 18, 24.

${ }^{104}$ Ibid. 
Animal Defenders International made clear how the principle will be applied: 'Where [national] legislators carefully weigh up the relevant human rights aspects of a piece of legislation, and seek to achieve a reasonable accommodation between individual rights and other aspects of public interest, the Court has shown itself inclined to accept the balance that has been struck'. ${ }^{105}$

The principle of subsidiarity is vital for protecting Convention rights: proper and efficient application of Convention obligations may restrain interference by European courts. The concept of subsidiarity conveys adherence to a political philosophy that puts the individual at the heart of social organisation. It is therefore not appropriate to view subsidiarity through the lens of society, but as a principle governing the organisation of society. As Millon-Delsol states: 'the question of the type of system comes after the question of the extent of government powers'. ${ }^{106}$ At its most rudimentary level, subsidiarity encapsulates the idea that political power should intervene only when society's organs, from the individual to the family, the local community and various larger groupings have not been able to resolve the issue on their own.

When a propagandist exercises their extreme individualistic right to create content that deceives, manipulates and harms other users, and that interferes with democratic deliberation and/or the information ecosystem, subsidiarity permits an authority's interference with one of the fundamental premises of the marketplace subjectivists' school of free expression: that there is no 'objective truth' and all opinions should be heard leaving the public to decide the most convincing. Thus, regulatory interference with free expression can be undertaken by national authorities. Furthermore, the European courts will only act as the arbiter of the 'balancing exercise' when deciding if rights have been infringed. Subsidiarity is not only vital for protecting Convention rights: proper and efficient application of Convention obligations may restrain interference by European courts, and the principle facilitates standard setting across member states with European judges learning from a variety of domestic contexts. Thus, subsidiarity permits national authorities to regulate against norms and to limit rights when the problem cannot be solved.

\section{SOLUTIONS}

In order to ensure transparency and that our democratic processes are not hijacked by those with the best technology, regulation of the advertising eco-system must be updated to reflect the scale of computational propaganda. Sometimes lawmakers rush to pass 'new' laws, labels and liabilities to fix what are perceived as novel problems posed by digital technologies. However, these remedies often come at the expense of the expertise and knowledge of existing regulators already in place. Rather than reclassifying platforms as something new or in between a platform and a publisher, ${ }^{107}$ regulators should be encouraged to develop trusted 'principle'based reforms to the regulation of political advertising underpinned by adherence to human rights frameworks.

At present, regulatory agencies that typically handle deceptive advertising generally refer claims of a political nature on to the UK's Electoral Commission where there is an understandable reluctance to interfere with political speech. Yet computational propaganda operates via an algorithmic output, rather than a human voice. They should be characterised by

\footnotetext{
105 Dean Spielmann, President of the European Court of Human Rights, Remarks to Yerevan University (3 July 2013) 3 <https://www.echr.coe.int/Documents/Speech_20130703_Spielmann_Yerevan_ENG.pdf> accessed 17 July 2019, referring to Animal Defenders International v The United Kingdom App no 48876/08 (ECtHR, 22 April 2013).

${ }^{106}$ Steering Committee on Local and Regional Authorities (CDLR) of the Council of Europe, Definition and Limits of the Principle of Subsidiarity: Local and Regional Authorities in Europe (Report No 55) 9, citing Chantal Millon-Delsol, Il principio di sussidiarietà (Giuffrè Editore, Milan 2003) 83.

${ }^{107}$ Digital, Culture, Media and Sport Committee (n 2), 10.
} 
the organs of the state tasked with regulating commercial speech and advertising as a deceptive communications. One of the reasons the Advertising Standards Agency (ASA) has legitimacy to regulate commercial speech is the consensus among commercial companies to be regulated. In addition to stifling democratic deliberation, one of the reasons that we have not regulated political speech is that there was no consensus among the participants for regulation. ${ }^{108}$ Following the 1997 general election, the ASA avoided any regulatory oversight of political advertising, arguing that it might damage the advertising industry's self-regulatory system if it were seen to have been deployed against one political party but not another. ${ }^{109}$ It also felt unable to rule sufficiently quickly to affect an election campaign. Presently, its Codes of Practice completely exempt political advertising. ${ }^{110}$ Furthermore, there is the practical side of regulating: asking Macedonian teenagers to sign-up to a voluntary code of practice or Russian trolls to submit to the jurisdiction of the courts in England and Wales would be an exercise in futility.

In response to numerous measures by the EU Commission and demands from national lawmakers to increase transparency and accountability, platforms agreed to a voluntary code of 'self-regulatory standards to fight disinformation' that aim to increase 'transparency in political advertising', close 'fake accounts' and demonetise financial incentives associated with the dissemination of disinformation. ${ }^{111}$ Platforms undertook initiatives to increase transparency and accountability. Facebook has implemented an authorisation procedure for all political and issue-based advertising and requires a 'paid-for' disclaimer on all ads. ${ }^{112}$ However, this is limited to specific electoral events. Facebook's new public repository permits users to see the number of political- and issue-based ads that were run in EU member states, along with information like aggregate advertiser expenditure and pages running each ad. ${ }^{113}$ Regulators, watchdogs and media will be able to take advantage of expanded access to Facebook's Application Programming Interface (API) to help increase accountability.

The repository is seen as a tool to be used by competing political advertisers to help offset the damage associated with psychometric targeting. The application of the "marketplace of ideas' ideology to the advertising ecosystem is problematic for a number of reasons. Political advertisements in the 'offline world' are attempts to influence voters into making some sort of decision. Broadcast political advertisements are educative and informative in nature; for example, an ad designed to explain a candidate's position on an issue (ie pro-life, anti-tax, progreen policies) or an attempt to convey a certain characteristic about the voter to the candidate (ie strong religious background, strong on national security, 'faith and family' etc). Transparency in broadcast political advertisements facilitate rebuttal by the other side. There are also significant financial constraints on how many political ads can be purchased via the medium of broadcasting in an election cycle, but little online. Market constraints ensure that the people producing content for broadcasting restrict the number of actors producing political content to those who have vested interests in ensuring that they comply with codes.

Regulating platform providers may be one solution to ensure the legitimacy of our democratic institutions and processes but it may be more appropriate to either use or change existing laws to achieve the same regulatory outcome. For example, take the US and the UK's

\footnotetext{
108 'Political advertising' (ASA, 21 July 2014) <https://www.asa.org.uk/news/political-advertising.html> accessed 6 December 2017.

${ }^{109}$ Ibid.

110 'CAP Code' (n 91) rule 7 (political advertisements).

111 Commission, 'Code of Practice on Disinformation' (26 September 2018) < https://ec.europa.eu/digital-singlemarket/en/news/code-practice-disinformation> accessed 4 July 2019.

112 Richard Allen, 'Protecting Elections in the EU' (Facebook Newsroom, 28 March 2019) <https://newsroom.fb.com/news/2019/03/ads-transparency-in-the-eu/> accessed 4 July 2019. ${ }^{113}$ Ibid.
} 
historical approach to regulating political advertising. The US approach focuses on ensuring that each side in national, state and local elections remains aware of what their opposition is saying. This is reflected in their 'market rebuttal' approach to democratic deliberation. ${ }^{114}$ The UK approach focuses on financial transparency, general/national election expenditure rules mandating specific limits on contributions. Ofcom's Broadcasting Code mandates a general prohibition on television advertisements, leaving parties allocated blocks of free airtime for party political broadcasts, which are labelled party election broadcasts during official campaign periods. ${ }^{115}$ Both the US and the UK approaches, by very different means, are designed to ultimately ensure that foreign states do not interfere with an individual's internal democratic deliberation. To achieve this means sensible and proactive restrictions on the right to free speech.

The ECtHR has stated that in the period before or during an election, it may be considered necessary 'to place certain restrictions, of a type which would not usually be acceptable, on freedom of expression' in order to secure the 'free expression of the opinion of the people in the choice of the legislature' ${ }^{116}$ In many instances, this may mean that additional regulation is imposed on traditional media outlets but, to date, none of the same restrictions apply to online media and social media platforms, arguably permitting deceptive practices to flourish during 'online political campaigns'. ${ }^{117}$ Yet, during the UK Parliamentary elections in 2015, £1.6 million was spent on political advertising through Facebook and Google alone. ${ }^{118}$ This figure was double the amount spent on campaign broadcasts and five times that spent on newspapers. This advertising was largely unregulated as the ASA does not regulate political advertising. ${ }^{119}$ Following the 1997 election, the ASA avoided any regulatory oversight of political advertising, arguing that it might damage the advertising industry's self-regulatory system if it were seen to have been deployed with bias toward one party. ${ }^{120}$

As a result, we have a regulatory anomaly. Political advertising is prohibited on legacy media outlets. Fixing this requires updating electoral law for the digital era and requires interagency and institutional cooperation. These rules should be designed to also protect and inform voters. Unlike other advertisers that have self-interest in preserving the trustworthiness of their brand through accurate advertising, social media platforms do not. Furthermore, an 'offline' commercial ad reflects a business's interest. An 'online' advertisement is designed to drive traffic to an external website with the 'landing page' only approved for satisfaction with a) technical requirements and b) an overview of the content. Facebook uses both human and

\footnotetext{
${ }^{114}$ See Lawrence Norden and Ian Vandewalker, 'This Bill Would Help Stop Russia From Buying Online Election Ads' (Slate, 19 October 2017) <https://slate.com/technology/2017/10/the-honest-ads-act-would-help-stop-online-election-meddling-fromforeign-governments.html> accessed 29 July 2019 noting that the Bipartisan Campaign Reform Act (2002) requires 'disclosure of the purchaser of TV and radio advertisements, and amended the original Federal Election Campaign Act of 1974 to prohibit foreign nationals (and governments) from engaging in such political spending'. The Federal Election Campaigns Act and Federal Electoral Commission Regulations include a broad prohibition on foreign national activity in connection with elections in the US. See generally 'Voting and Elections: Contributions and Donations by Foreign Nationals' Title 52 USC $\S 30121$ and 'Prohibition on Contributions, Donations, Expenditures, Independent Expenditures, and Disbursements by Foreign Nationals' 11 CFR 110.20 .

${ }^{115}$ Isobel White and Oonagh Gay, 'Party Political Broadcasts' (House of Commons Library, Standard Note SN/PC/03354, 17 March 2015) 3 <http://researchbriefings.files.parliament.uk/documents/SN03354/SN03354.pdf> accessed 29 July 2019.

${ }_{116}$ Bowman v The United Kingdom App no 24839/94 (ECtHR, 19 February 1998) para 43.

117 Council Resolution 2143 of 2017, 'Online Media and Journalism: Challenges and Accountability' <http://cedem.org.ua/en/library/online-media-and-journalism-challenges-and-accountability/> accessed 30 May 2019.

118 'Party spending in the UK Parliamentary Election' (The Electoral Commission, 2015)

$<$ http://search.electoralcommission.org.uk/Search/Spending?currentPage=1\&rows=20\&sort=TotalExpenditure\&order=desc $\& \mathrm{tab}=1 \& \mathrm{et}=\mathrm{pp} \& \mathrm{evt}=\mathrm{ukparliament} \& \mathrm{ev}=445 \& \mathrm{optCols}=$ ExpenseCategoryName \&optCols=AmountInEngland\&optCols=Amo untInScotland\&optCols=AmountInWales\&optCols=AmountInNorthernIreland\&optCols=DatePaid $>$ accessed 18 July 2019. 119 'CAP Code' (n 91) rule 7 (political advertisements).

120 Guy Parker, 'The ASA Can't Regulate Political Advertisements. Here's Why' (The Guardian, 6 July 2016) <https://www.theguardian.com/commentisfree/2016/jul/06/advertising-standards-authority-political-advertisements> accessed 29 July 2019.
} 
automated processes 'to make sure that they meet our Advertising Policies' for political advertising. ${ }^{121}$ This follows the industry standard approach for self-regulation among commercial advertisers that have normally operated in 'offline' environments traditionally constrained by good business practices and the CAP Code, and brings political advertising into the realm of regulation and licensing. ${ }^{122}$

Under the principle of subsidiarity, political advertising should be overseen by a coregulatory arrangement between Ofcom and the ASA in a manner that mirrors the existing model for the regulation of broadcast advertising. Previous examples of advertising associations working in partnership with Ofcom facilitated the contracting of broadcast advertising to the ASA. These industry proposals resulted in the Ofcom Code, with the regulator retaining the power to amend when deemed appropriate. Due to trust in the industry through its own self-regulation, this power has been used rather sparingly. In this proposal, Ofcom would have the statutory authority to oversee the licensing of political advertisers, with the ASA continuing its self-regulation of the advertising practices.

Any new political advertising code should be built upon principles of transparency and accountability and deploy them in a way that encourages a responsible market for digital political advertising. All platforms that sell political advertising should hold a copy of the ad in a public repository alongside metadata about the ad. Not only will marketing transparency increase accountability, the creation of a repository will stimulate economic growth by creating markets for competing campaigns. All public repositories should be downloadable in machine readable language and contain such information including, but not limited to ownership, the landing page associated with the ad, how long the ad was visible, any interactions with the ad etc. Metadata should be held in a searchable publicly accessible interface. This obligation should be independent of any current data protection legislation and would ensure accountability and scrutiny for all political advertising visible on users' pages.

The transparency principle ensures users have the right to access information about who has targeted them and by what means. Access to machine readable data about targeted advertisements would help voters compare and contrast the validity of the idea directed at them, ensuring the possibility of plurality in thinking rather than subservience to who has the best profiling technology in a given election cycle. Licensing ensures not only transparency in advertisement but transparency in the actors behind profiling and data analytics. This marketfriendly approach does not restrict markets but ensures transparency and accountability across the advertising eco-system. Platforms should be legally prohibited from permitting advertisements during restricted periods from non-licensed advertisers. This reflects a hybrid approach that mirrors regulating political advertising in the 'offline' world while preserving the integrity of the electoral process within human rights frameworks that permit restrictions on free speech when 'necessary in a democratic society'. ${ }^{123}$

\section{CONCLUSION}

Attempts to regulate private propaganda can be traced back to the League of Nations and preliminary deliberations for the UN Charter. Ideological divides on either side of the Iron Curtain frustrated third-world countries wishing to have some say over the influence others exerted over their sovereignty through the use of propaganda. The West's 'marketplace of ideas' won at the expense of the Soviet-favoured approach of having media controlled and

121 ‘Advertising Policies’ (Facebook, 2019) <https://www.facebook.com/policies/ads/> accessed 29 July 2019 (emphasis added).

122 The definitions of 'political' for the purposes of an advertiser's status and for the content of advertisements is set out in Communications Act 2003 (UK), s 321.

${ }^{123}$ ECHR, art 10(2). 
heavily regulated by the state. For 60 years, this status quo served both sides well, especially when print media and broadcasting were the primary, if not the sole systems for disseminating content. However, advances in digital technologies have broadened the methods available for dissemination and added efficiencies to mass advertising. Psychometric profiling and A/B testing can measure user responses to stimuli and can help target propaganda without any corrections or the counterbalance that the marketplace of ideas normally provides.

Regulators have responded by emphasising the role of the EU's data protection regime to control the dissemination of computational propaganda. Many of the methods discussed above require the analysis of personal data and automated processes; however, the GDPR prohibits the processing of personal data through a list of prohibitive grounds. However, once a data controller satisfies certain conditions, systematic psychometric profiling and targeting propaganda can theoretically take place. Even if national data protection agencies find a way to raise the threshold of consent to such a level that it is virtually impossible, demographicbased advertising would still be permitted. As much of computational propaganda is delivered through advertising-based content, and Facebook's delivery system makes the platform an advertising publisher, the legal justification for regulating the actor and political advertising content is satisfied. At user level, the marketplace of ideas should be permitted to flow and operate as normal. At system level, processes associated with using personal data to target and deliver computational propaganda should be regulated. Finally, to ensure the appropriateness of material targeted at voters, proper advertising regulation is needed at content level. 